\title{
A Case Study for Estimation of Heating Energy Requirement and Fuel Consumption in a Prototype Building Using Degree-Day Method in Kocaeli
}

\author{
Cenker Aktemur \\ *Department of Mechanical Engineering, Eastern Mediterranean University, via Mersin 10, Famagusta, N.Cyprus \\ (cenkeraktemur_41@hotmail.com)
}

\begin{abstract}
* Corresponding Author; Cenker Aktemur, Department of Mechanical Engineering, Eastern Mediterranean University, via Mersin 10,
Famagusta, N.Cyprus, Tel: +95382660367,

cenkeraktemur_41@hotmail.com
\end{abstract}

Received: 24.03.2017 Accepted: 12.04.2017

\begin{abstract}
Energy is a requirement of all industrialised nations, and variations in its availability can be dangerous and disruptive. The majority of the energy consumed in buildings is spent for heating and cooling to ensure the thermal comfort of human beings in all parts of the world. Energy analysis plays a vitally important in the design of heating, ventilation and air conditioning (HVAC) systems at affordable and efficient cost in residential areas. Buildings are in need of heating in cold weather. The mean daily outside air temperature is an important guide in predicting the amount of fuel needed to heat residential buildings. The amount of fuel required to heat an area, a city or a region can be accurately forecasted based on the outside air temperature. One of the well-accepted methods internationally is the heating degree-day (HDD) method, which is employed for the energy analysis. This paper considers for İzmit, the capital district of Kocaeli province, which is located on the western coast of Turkey and aims to calculate the annual heating energy requirement and natural gas consumption at a base temperature of $150 \mathrm{C}$ by considering different type of glass, glazing area percentage (GAP), air exchange rate (ACH), and the number of people (n) living in a prototype building. It was predicted that in the worst condition (single-glazing), natural gas consumption would be about fourfold higher than the best condition (triple-glazing) if it is thought that 60 people live in an apartment building.
\end{abstract}

Keywords Energy analysis, heating degree-day, heating energy requirement, natural gas consumption, prototype building.

\section{Introduction}

Energy is fundamental to meet many human needs, including lighting, cooking, heating and traveling. The swiftly growing world population, escalating energy demands and industrialisation of countries have resulted in high energy costs and environmental problems; therefore, studies that focus on cutting unnecessary costs have been gaining prominence. Energy consumption can be generally examined in four major sectors, namely industry, building, transportation and agriculture. In almost all countries, energy consumption in buildings constitutes a substantial part of total energy consumption. Roughly $25-30 \%$ of the total energy consumption in Turkey occurs in residential buildings. The energy in buildings is mainly employed in heating, domestic water preperation and cooking. Heating is the largest part of energy consumption in the buildings with $40 \%$. Therefore, the amount of energy required to heat buildings is a very important step and must be focused it on painstakingly [1-3].

The seasonal energy requirements for the heating of buildings and the associated fuel consumption can be determined depending on the predetermined architectural design, the material characteristics of the buildings and meteorological temperature measurements. Design of conditioning systems, energy analysis in buildings, heating and cooling load calculations are mainly based on climate data [4].

Various energy estimation methods have been developed for buildings and climate systems. One of the methods of predicting the energy requirement for heating building in a given time of period is the degree-day (DD) method [5]. The method assumes that the energy requirement of a building is directly proportional to the difference between the outdoor and indoor air temperatures. Heating calculations are performed 
for periods of time provided that the outdoor temperature is lower than a base temperature [6].

\section{Literature review}

The first work in the sense of degrees-days (DDs) in the world was conducted in the 1700's and studies in this direction accelerated in the 20th century. In Turkey, however, a number of studies be on this subject after the 1980s. The first DD study is based on the relationship between plant growth and temperature. The first serious study related to DD was carried out by French scientist Reaumur in the 18th century. Today, DD technique has been further developed and been continued to be employed incessantly for many purposes by researchers. Some of these are energy demand, fuel consumption, and cost analysis which are substantial parameters for the energy management of the buildings [7].

Durmayaz et al. (2000) [8] conducted a study on Istanbul's energy needs and fuel consumption using heating degreehours technique. In the study, a prototype apartment was planned in Göztepe province of Turkey and they assumed that 20-65 people live in the apartment. Basic parameters such as heating energy demand and fuel consumption, the number of hourly air changes, the number of people in the apartment and the population of the city were used. They explained that this method can easily be used in similar applications for any part of the world.

Dagsoz (1995) [9] utilized for heating and cooling purposes using degree-day method. He calculated HDD at base temperatures of 12 and $18{ }^{\circ} \mathrm{C}$ using the 10-year average temperature data for 67 provinces in Turkey and tried to determine the heating fuel requirement of the buildings.

Sarak and Satman (2003) [10] tried to estimate natural gas demand using heating degree day (HDD) method that is required for the heating of buildings in Turkey. Daily temperatures of cities, population and settlement records of buildings were obtained to predict Turkey's natural gas demand. They estimated that the maximum amount of potential natural gas consumption would be $14.92 \mathrm{Gm} 3$ in 2023.

Akbayir (2006) [11] aimed to calculate the daily heating and cooling degree days for Eskişehir province of Turkey. He determined that fuel consumption in Eskişehir is at most 18.2 $\%$ in January.

Kaynakli (2008) [12] calculated degree-hours (DH) values considering mean outside air temperature from 1992 to 2005 in İstanbul province of Turkey. Then, he investigated for different architectural design properties such as air infiltration rate, glazing type, and area to determine the heating energy requirement and fuel consumption calculations on single and double-glazing, various type of material used.

Durmayaz and Kadioglu (2003) [13] estimated the seasonal energy demand and fuel consumption in a building for the major cities of Turkey such as Istanbul, Ankara, Adana, Bursa and Konya by using degree-hour (DH) method. Since $50.8 \%$ of the total population in Turkey is thought to be in these big city centres, it was stated that the total amount of these estimates can be interpreted as a good indicator of the energy demand and fuel consumption of buildings in all major cities of Turkey.

\section{Heating degree-day method}

While climate data are presented in different ways for different purposes, the complexity and truthfulness of the methods developed are relied on the detailed climate data used. Accepted methods for estimating energy use of buildings in the early 1970s are developed for the need to forecast the energy usage at the macro level. One of the methods employed for the heating energy calculations is degree-day (DD) calculation method. It is the most common method since it gives very good results in energy consumption calculations for heating purposes. For several provinces it is possible to compile DD values calculated by different researchers at different base temperatures. Degree-days (DDs), the cumulative sum of the differences between the mean outdoor air temperature and base temperature, can be calculated for a specific period of time (e.g., day, week, month, or year), and they are determined only by the positive values of the temperature difference [14]. Countries employ several techniques to calculate DD. To create a comparable and common use, Statistical Office Of The European Communities (EUROSTAT) proposes the following equation (1) in terms of the entire heating season for the calculation of the total number of HDD [15].

$$
\begin{aligned}
& \operatorname{HDD}=\sum_{\mathrm{j}=1}^{\mathrm{N}}\left(\mathrm{T}_{\mathrm{b}}-\mathrm{T}_{\mathrm{o}, \mathrm{j}}\right) \text { if }\left(\mathrm{T}_{\mathrm{o}}<\mathrm{T}_{\mathrm{b}}\right) \\
& \mathrm{HDD}=0 \text { if }\left(\mathrm{T}_{\mathrm{o}}>\mathrm{T}_{\mathrm{b}}\right)
\end{aligned}
$$

where $T_{b}$ is base temperature, $T_{o, j}$ is daily mean outside air temperature recorded at a meteorology station, as indicated in the following equation (2), $N$ is the number of days provided that $T_{o}<T_{b}$ in a heating season. Therefore, HDD values are calculated as $T_{o}<T_{b}$. As it can be seen from equation (2), HDD values only take on positive values.

The daily mean outdoor air temperature, $T_{o}$, is determined by taking the average of the measured maximum and minimum temperatures during a day.

$\mathrm{T}_{\mathrm{o}}=\frac{\left(\mathrm{T}_{\mathrm{o}, \text { min }}+\mathrm{T}_{\mathrm{o} \text {, max }}\right)}{2}$

where $T_{o}$, min and $T_{o}, \max$ are, in turn, minimum and maximum temperatures recorded during a day $\left[{ }^{\circ} \mathrm{C}\right]$.

\section{Practical calculations and interprations}

Thermal conductivities and thicknesses of the construction materials are determined for an insulated building. $U$-values of outside walls, single, double and triple glazed windows, floor and roof are calculated as $0.54,5.8,2.7,0.85,032$ and $0.51 \mathrm{~W} / \mathrm{m}^{2} \mathrm{~K}$. A brief summary of physical and thermal properties of building construction materials is presented in Table 1 below. 
Table 1. Physical and thermal properties of building construction materials

\begin{tabular}{|c|c|c|c|c|c|}
\hline Element & $\begin{array}{c}\text { Area } \\
\left(\mathbf{m}^{2}\right)\end{array}$ & Material & $\begin{array}{l}\text { Conductivity } \\
(\mathrm{W} / \mathrm{m}-\mathrm{K})\end{array}$ & $\begin{array}{l}\text { Thickness } \\
\text { (m) }\end{array}$ & $\begin{array}{c}\text { U-value } \\
\left(\mathbf{W} / \mathbf{m}^{2}-\mathbf{K}\right)\end{array}$ \\
\hline \multirow{3}{*}{$\begin{array}{l}\text { Ceiling } \\
\text { under the } \\
\text { roof }\end{array}$} & \multirow{3}{*}{504} & Insulation (fiberglass) & 0.038 & 0.07 & \multirow{3}{*}{0.51} \\
\hline & & $\begin{array}{l}\text { Concrete with sand and } \\
\text { gravel aggregate }\end{array}$ & 2.1 & 0.16 & \\
\hline & & $\begin{array}{c}\text { Cement plaster with sand } \\
\text { aggregate }\end{array}$ & 0.72 & 0.04 & \\
\hline \multirow{5}{*}{$\begin{array}{l}\text { Outside } \\
\text { walls }\end{array}$} & \multirow{5}{*}{$\begin{array}{l}2208 \text { minus } \\
\text { glazing area }\end{array}$} & $\begin{array}{c}\text { Cement plaster with sand } \\
\text { aggregate }\end{array}$ & 0.72 & 0.02 & \multirow{5}{*}{0.54} \\
\hline & & Brickwork & 0.84 & 0.075 & \\
\hline & & Insulation (Glass wool) & 0.034 & 0.05 & \\
\hline & & Brickwork & 0.84 & 0.075 & \\
\hline & & $\begin{array}{c}\text { Cement plaster with sand } \\
\text { aggregate }\end{array}$ & 0.72 & 0.02 & \\
\hline \multirow{3}{*}{ Windows } & \multirow{3}{*}{$\begin{array}{c}15,20,25,30,35 \\
40,45,50 \% \\
\text { of outside walls }\end{array}$} & Single glass & & & 5.8 \\
\hline & & Double glass & & & 2.7 \\
\hline & & Triple glass & & & 0.85 \\
\hline \multirow{4}{*}{ Basement } & \multirow{4}{*}{504} & Laminate & 0.13 & 0.007 & \multirow{4}{*}{0.32} \\
\hline & & Cement mortar & 1.73 & 0.05 & \\
\hline & & Extrude polystren foam & 0.035 & 0.1 & \\
\hline & & Unreinforced concrete & 1.65 & 0.2 & \\
\hline
\end{tabular}

Daily means of external air temperatures over the heating season are indicated in Fig.1. The total number of heating degree-days is forecasted as 1407 at a base temperature of 15 ${ }^{\circ} \mathrm{C}$ for the heating season in Kocaeli (latitude $40^{\circ} 47^{\prime} \mathrm{N}$, longitude $29^{\circ} 58 \mathrm{E}$ ) by the aid of Figure 1 and equation (1).

According to TS 825 (Thermal Insulation Rules of Buildings) [16], Turkey is divided into four climatic zones depending on DD values determined according to the average temperatures for heating. Kocaeli, the reference province located in the second climate region, was inspected in detail to determine the mean outside air temperatures in 2016. The daily mean outdoor air temperature variation between 2015 and 2016, based on the records of İzmit meteorology station, is exemplified conjunction with a fitted polynomial function of the 4th order in Figure 1 below. It is possible to infer that parabolic DD alterations occur because Kocaeli transitions between Mediterranean and Black Sea climates. The base temperature is determined according to the comfort needs of human beings and is a major influence on the starting date of a building's heating season. Fig. 2 below are employed for determination of the starting and end of the heating season. The 266th day (22 September) and 149th day (28 May) of the year appear as the beginning and end of the heating season if $T_{b}=15^{\circ} \mathrm{C}$ is considered. It is seen that the heating season lasts 236 days within the year, which means that it encompasses approximately $55 \%$ of the heating season and it is clearly understood that there is no requirement for the heating between the 150th and 265th days of the year in Kocaeli. According to ASHRAE [17], it is necessary to properly and adequately ventilate the structure in order to meet the oxygen requirements for the maintenance of human life and to remove the air pollution that can occur for various reasons in the structure. Ventilation can be provided by the use of building systems or by natural means. Provision of natural ventilation on the buildings is more favorable than energy conservation, economy and health systems. However, in order to ventilate by means of natural methods, appropriate external air must reach the structure and this air must be absorbed into the structure through the building's shell and ensuring adequate and proper air circulation within the structure and then the polluted air is needed to be removed from the structure.

Let us assume $I(\mathrm{ACH})$ for hourly average air exchange rate, $I$ $=0.5 \mathrm{ACH}, 1.0 \mathrm{ACH}, 1.5 \mathrm{ACH}$, and 2.0 $\mathrm{ACH}$ depending on the ventilation spacings. Besides, we take the glazed area percentages as $15 \%\left(352.8 \mathrm{~m}^{2}\right), 20 \%\left(470.4 \mathrm{~m}^{2}\right), 25 \%(588$ $\left.\mathrm{m}^{2}\right), 30 \%\left(705.6 \mathrm{~m}^{2}\right), 35 \%\left(823.2 \mathrm{~m}^{2}\right), 40 \%\left(940.8 \mathrm{~m}^{2}\right), 45 \%$ $\left(1058.4 \mathrm{~m}^{2}\right)$ and $50 \%\left(1176 \mathrm{~m}^{2}\right)$ with respect to the total outside wall area.

The prototype, 7-story apartment building, in which it is assumed that $40,45,50,55,60,65,70,75,80,85,90,95$ or 100 people may live, is placed in İzmit (capital district of Kocaeli). The outside dimensions, widt $\times$ depth $\times$ height, of this building are taken into account as $28 \times 18 \times 24 \mathrm{~m}$. It is thought to be 36 residences in this building. Area of roof, outside walls, and floor is $504 \mathrm{~m}^{2}, 2208 \mathrm{~m}^{2}$ and $504 \mathrm{~m}^{2}$, respectively and total building volume is $\mathrm{V}=12096 \mathrm{~m} 3$. According to these, the building's total heat loss coefficient, $\mathrm{L}(\mathrm{W} / \mathrm{K})$, various glazing area percentage of outside walls, GAP, and I is calculated through the following equation (4) [18]: 


$$
L=\sum \frac{\mathrm{UA}+\mathrm{I}\left(\rho \mathrm{c}_{\mathrm{p}}\right)_{\mathrm{air}} \mathrm{V}}{3.6}=\sum \frac{\mathrm{UA}+\mathrm{IV}}{3}
$$

because the volumetric thermal capacity of air is $\left(\rho c_{p}\right)_{\text {air }}=1.2$ $\mathrm{kJ} / \mathrm{m}^{3} \mathrm{~K}$. Then, the results are tabulated in Table 2.

\section{Determination of heating energy requirement and fuel consumption}

Seasonal heating energy requirement, $Q(\mathrm{~J})$, for prototype building, located in Kocaeli is calculated adopting the following equation (5) in respect of HDDs and the total heat loss coefficients $(L)$ [19].

$\mathrm{Q}=\frac{\mathrm{L} \cdot \mathrm{HDD}_{\mathrm{y}} \cdot \frac{24 \mathrm{~h}}{1 \mathrm{day}} \cdot \frac{3600 \mathrm{~s}}{1 \mathrm{~h}}}{\left(\mathrm{~T}_{\mathrm{i}}-\mathrm{T}_{\mathrm{o}}\right)}$
Equation (5) is simplified as follows:

$Q=\frac{86400 \cdot \mathrm{L} \cdot \mathrm{HDD}_{\mathrm{y}}}{\left(\mathrm{T}_{\mathrm{i}}-\mathrm{T}_{\mathrm{o}}\right)}$

where $Q$ is energy demand $(\mathrm{J}), L$ is the total heat loss coefficient of the building $\left(\mathrm{W} /{ }^{\circ} \mathrm{C}\right), H D D$ is the total number of DDs in a year for the heating period $\left({ }^{\circ} \mathrm{C}\right.$.day) and $T_{i}-T_{o}$ is design indoor and outdoor air temperature difference $\left({ }^{\circ} \mathrm{C}\right)$.

Following the determination of the total heat coefficients, the heating energy requirements are given in GJ in Table $\mathbf{3}$ below for single, double and triple glass, various GAP and $I$.

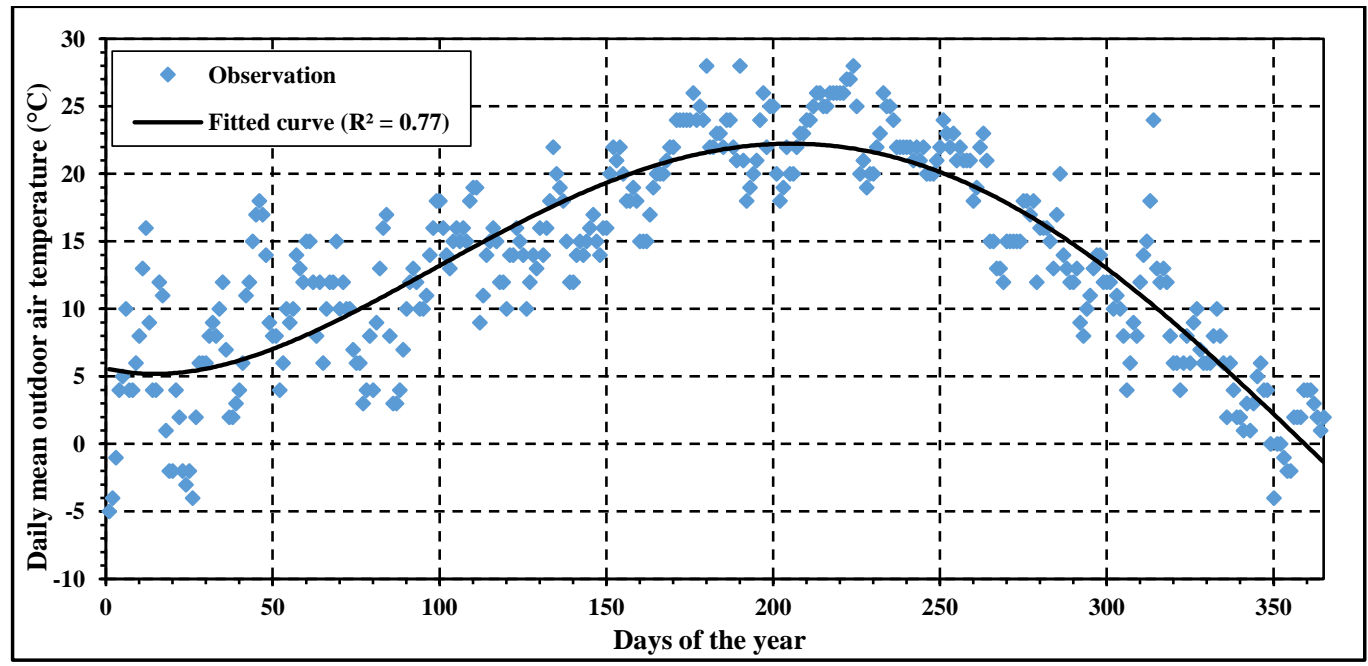

Fig. 1. Variation of daily outdoor air temperatures for Kocaeli in 2016.

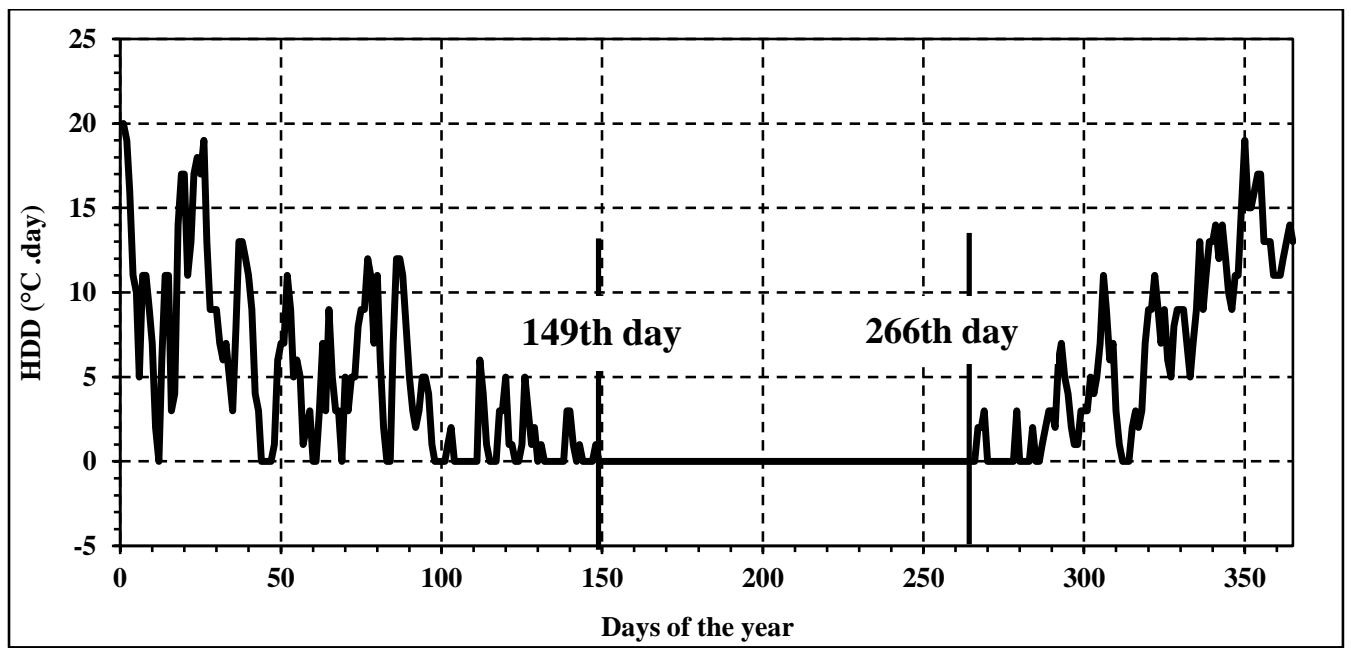

Fig. 2. Alteration of daily HDD at a base temperature of $15^{\circ} \mathrm{C}$ in 2016 . 
Table 2. Building heat loss coefficient $L(\mathrm{~W} / \mathrm{K})$ for various glazing type and surface area GAP, and air infiltration rate $I$.

\begin{tabular}{|c|c|c|c|c|c|c|c|c|c|}
\hline \multirow{2}{*}{ Glass } & \multirow{2}{*}{$\mathbf{A C H}$} & \multicolumn{8}{|c|}{ GAP $(\%)$} \\
\hline & & 15 & 20 & 25 & 30 & 35 & 40 & 45 & 50 \\
\hline \multirow{4}{*}{ Single } & 0,5 & 5560,1 & 6178,7 & 6797,3 & 7415,9 & 8034,4 & 8653,0 & 9271,6 & 9890,2 \\
\hline & 1 & 7576,1 & 8194,7 & 8813,3 & 9431,9 & 10050,4 & 10669,0 & 11287,6 & 11906,2 \\
\hline & 1,5 & 9592,1 & 10210,7 & 10829,3 & 11447,9 & 12066,4 & 12685,0 & 13303,6 & 13922,2 \\
\hline & 2 & 11608,1 & 12226,7 & 12845,3 & 13463,9 & 14082,4 & 14701,0 & 15319,6 & 15938,2 \\
\hline \multirow{4}{*}{ Double } & 0,5 & 4466,4 & 4720,5 & 4974,5 & 5228,5 & 5482,5 & 5736,5 & 5990,5 & 6244,6 \\
\hline & 1 & 6482,4 & 6736,5 & 6990,5 & 7244,5 & 7498,5 & 7752,5 & 8006,5 & 8260,6 \\
\hline & 1,5 & 8498,4 & 8752,5 & 9006,5 & 9260,5 & 9514,5 & 9768,5 & 10022,5 & 10276,6 \\
\hline & 2 & 10514,4 & 10768,5 & 11022,5 & 11276,5 & 11530,5 & 11784,5 & 12038,5 & 12292,6 \\
\hline \multirow{4}{*}{ Triple } & 0,5 & 3813,8 & 3850,2 & 3886,7 & 3923,1 & 3959,6 & 3996,0 & 4032,5 & 4069,0 \\
\hline & 1 & 5829,8 & 5866,2 & 5902,7 & 5939,1 & 5975,6 & 6012,0 & 6048,5 & 6085,0 \\
\hline & 1,5 & 7845,8 & 7882,2 & 7918,7 & 7955,1 & 7991,6 & 8028,0 & 8064,5 & 8101,0 \\
\hline & 2 & 9861,8 & 9898,2 & 9934,7 & 9971,1 & 10007,6 & 10044,0 & 10080,5 & 10117,0 \\
\hline
\end{tabular}

Table 3. Estimations of the heating energy requirements of an apartment building

\begin{tabular}{|c|c|c|c|c|c|c|c|c|c|}
\hline \multirow{2}{*}{ Glass } & \multirow{2}{*}{$\mathrm{ACH}$} & \multicolumn{8}{|c|}{ GAP (\%) } \\
\hline & & 15 & 20 & 25 & 30 & 35 & 40 & 45 & 50 \\
\hline \multirow{4}{*}{ Single } & 0,5 & 675,9 & 751,1 & 826,3 & 901,5 & 976,7 & 1051,9 & 1127,1 & 1202,3 \\
\hline & 1 & 921,0 & 996,2 & 1071,4 & 1146,6 & 1221,8 & 1297,0 & 1372,2 & 1447,4 \\
\hline & 1,5 & 1166,1 & 1241,3 & 1316,5 & 1391,7 & 1466,9 & 1542,1 & 1617,2 & 1692,4 \\
\hline & 2 & 1411,1 & 1486,3 & 1561,5 & 1636,7 & 1711,9 & 1787,1 & 1862,3 & 1937,5 \\
\hline \multirow{4}{*}{ Double } & 0,5 & 543,0 & 573,8 & 604,7 & 635,6 & 666,5 & 697,4 & 728,2 & 759,1 \\
\hline & 1 & 788,0 & 818,9 & 849,8 & 880,7 & 911,6 & 942,4 & 973,3 & 1004,2 \\
\hline & 1,5 & 1033,1 & 1064,0 & 1094,9 & 1125,8 & 1156,6 & 1187,5 & 1218,4 & 1249,3 \\
\hline & 2 & 1278,2 & 1309,1 & 1339,9 & 1370,8 & 1401,7 & 1432,6 & 1463,5 & 1494,3 \\
\hline \multirow{4}{*}{ Triple } & 0,5 & 463,6 & 468,1 & 472,5 & 476,9 & 481,3 & 485,8 & 490,2 & 494,6 \\
\hline & 1 & 708,7 & 713,1 & 717,6 & 722,0 & 726,4 & 730,9 & 735,3 & 739,7 \\
\hline & 1,5 & 953,8 & 958,2 & 962,6 & 967,1 & 971,5 & 975,9 & 980,4 & 984,8 \\
\hline & 2 & 1198,8 & 1203,3 & 1207,7 & 1212,1 & 1216,6 & 1221,0 & 1225,4 & 1229,9 \\
\hline
\end{tabular}

Fig. 3 shows the need for seasonal heating energy (GJ) in the prototype building in Kocaeli, together with the equations for both single, double and triple glasses, versus GAP. It can be seen how the seasonal heating energy requirement changes with GAP.

In a similar way, Fig. 4 displays the seasonal heating energy requirement for the prototype building in Kocaeli for $\mathrm{I}=1.0$ $\mathrm{ACH}$ versus different GAP. It is possible to infer that as the air exchange rate enhances, the need for seasonal heating energy also increases dramatically.

A point to be emphasized is the number of people living in an apartment, n, of course, when this value is taken, the number of apartments in the city must be detected. In this case study, necessary calculations were made considering that the population of the city lived utterly in the apartment.
For apartment buildings in the city, the total fuel consumption in a heating season can easily be calculated by aid of the following equation (7) [18].

$F=\frac{Q \times P}{\eta \times H \times n}$

where $F$ is the total fuel consumption $\left(\mathrm{m}^{3}\right), \mathrm{Q}$ is energy demand $(\mathrm{J}), \mathrm{P}$ is population of the city, LHV is lower heating value of natural gas $\left(\mathrm{J} / \mathrm{m}^{3}\right)$ and $\eta$ is the heating-system efficiencies so-called the thermal efficiency of the burning equipments.

Some assumptions were made in this case study: The average population for Kocaeli city is $1,830,772$, the heating value of natural gas is $\mathrm{H}=34.526 \mathrm{~J} / \mathrm{m}^{3}$, and the thermal efficiency is 0.88 [19]. 


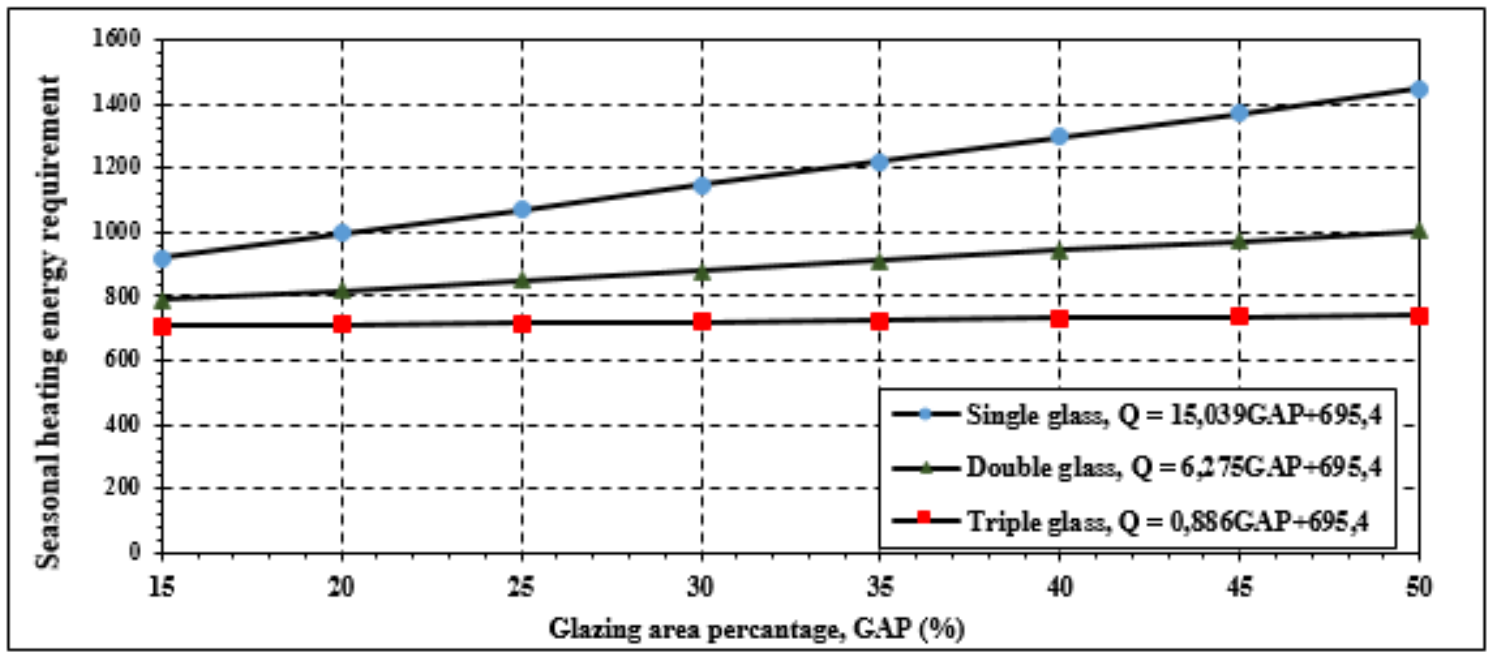

Fig. 3. Seasonal heating energy requirement for the prototype apartment building in Kocaeli for $I=1.0 \mathrm{ACH}$ versus different glazing area percentages.

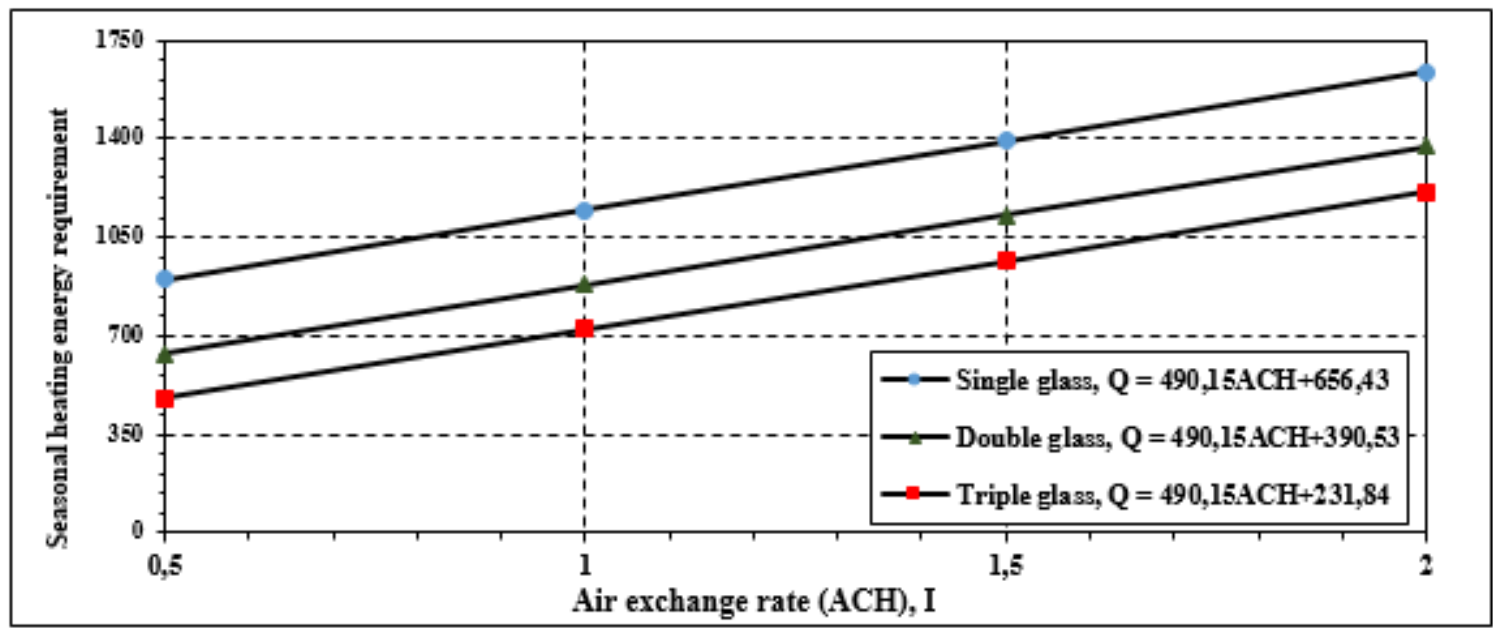

Fig. 4. Seasonal heating energy requirement for the prototype apartment building in Kocaeli for GAP=30\% versus various air exchange rates.

Fig. 5 presents seasonal natural gas consumption considering single-, double-, and triple-glazed windows for $\mathrm{GAP}=35 \%$ and $\mathrm{I}=1.0 \mathrm{ACH}$ versus number of people living in an apartment building. It is deduced from the Fig. 5 that as the number of people living in apartment buildings increases, the amount of natural gas used for annual heating decreases gradually.

Fig. 6 shows the annual amount of natural gas used for heating purpose based on the number of people living in an apartment building considering the best, the average and the worst conditions. The best case is that the triple-glazing is to be air exchange rate $(\mathrm{I}=0.5)$ and glazing area percentage $(\mathrm{GAP}=15 \%)$. The average case is that double-glazing is to be air exchange rate $(\mathrm{I}=1.0)$ and glazing area percentage $(\mathrm{GAP}=30 \%)$. The worst case is that single-glazing is to be air exchange rate $(\mathrm{I}=2.0)$ and glazing area percentage $(\mathrm{GAP}=50 \%)$. To illustrate, natural gas consumption will be approximately $0.46,0.86$ and 1.9 billion $\mathrm{m}^{3}$ (bcm), respectively, in an apartment building where 60 people live, taken into consideration these three cases. Natural gas consumption in the worst condition is nearly fourfold than the best condition.

Table 4 are created to forecast natural gas consumption for different GAP and I. If 85 people are considered to live in the best condition in an apartment building (triple glass; $0.5 \mathrm{ACH}$ and $\mathrm{GAP}=15 \%$ ), the natural gas consumption value is roughly $0.32 \mathrm{bcm}$, as demonstrated in Fig. 6. The actual consumption value taken from IZGAZ is between 0.3 and $0.4 \mathrm{bcm}$ in 2015 . 
Table 4. Estimation for the natural gas consumption $(\mathrm{bcm})$ during the heating season in Kocaeli if all heating energy requirements are provided by natural gas.

\begin{tabular}{|c|c|c|c|c|c|c|c|c|c|c|c|c|c|}
\hline \multirow{2}{*}{$\begin{array}{l}\text { No. of people } \\
\text { living in an } \\
\text { apartmant } \\
\text { building }\end{array}$} & \multirow[b]{2}{*}{$\begin{array}{r}\text { GAP } \\
(\%)\end{array}$} & \multicolumn{4}{|c|}{ Single glass } & \multicolumn{4}{|c|}{ Double glass } & \multicolumn{4}{|c|}{ Triple glass } \\
\hline & & $\begin{array}{c}0.5 \\
\mathrm{ACH}\end{array}$ & $\begin{array}{c}1.0 \\
\mathrm{ACH}\end{array}$ & $\begin{array}{c}1.5 \\
\mathrm{ACH}\end{array}$ & $\begin{array}{c}2.0 \\
\mathrm{ACH}\end{array}$ & $\begin{array}{c}0.5 \\
\mathrm{ACH}\end{array}$ & $\begin{array}{c}1.0 \\
\mathrm{ACH}\end{array}$ & $\begin{array}{c}1.5 \\
\mathrm{ACH}\end{array}$ & $\begin{array}{c}2.0 \\
\mathrm{ACH}\end{array}$ & $\begin{array}{c}0.5 \\
\mathrm{ACH}\end{array}$ & $\begin{array}{c}1.0 \\
\mathrm{ACH}\end{array}$ & $\begin{array}{c}1.5 \\
\mathrm{ACH}\end{array}$ & $\begin{array}{c}2.0 \\
\mathrm{ACH}\end{array}$ \\
\hline \multirow{8}{*}{40} & 15 & 1.0 & 1,36 & 1,72 & 2,08 & 0,80 & 1,16 & 1,52 & 1,88 & 0,68 & 1,04 & 1,40 & 1,77 \\
\hline & 20 & 1,11 & 1,47 & 1,83 & 2,19 & 0,85 & 1,21 & 1,57 & 1,93 & 0,69 & 1,05 & 1,41 & 1,77 \\
\hline & 25 & 1,22 & 1,58 & 1,94 & 2,30 & 0,89 & 1,25 & 1,61 & 1,97 & 0,70 & 1,06 & 1,42 & 1,78 \\
\hline & 30 & 1,32 & 1,69 & 2,05 & 2,41 & 0,94 & 1,30 & 1,66 & 2,02 & 0,70 & 1,06 & 1,42 & 1,79 \\
\hline & 35 & 1,44 & 1,80 & 2,16 & 2,52 & 0,98 & 1,34 & 1,70 & 2,06 & 0,71 & 1,07 & 1,43 & 1,79 \\
\hline & 40 & 1,55 & 1,91 & 2,27 & 2,63 & 1,03 & 1,39 & 1,75 & 2,11 & 0,72 & 1,08 & 1,44 & 1,80 \\
\hline & 45 & 1,66 & 2,02 & 2,38 & 2,74 & 1,07 & 1,43 & 1,79 & 2,16 & 0,72 & 1,08 & 1,44 & 1,80 \\
\hline & 50 & 1,77 & 2,13 & 2,49 & 2,85 & 1,12 & 1,48 & 1,84 & 2,20 & 0,73 & 1,09 & 1,45 & 1,81 \\
\hline \multirow{8}{*}{45} & 15 & 0,89 & 1,21 & 1,53 & 1,85 & 0,71 & 1,03 & 1,35 & 1,67 & 0,61 & 0,93 & 1,25 & 1,57 \\
\hline & 20 & 0,98 & 1,30 & 1,63 & 1,95 & 0,75 & 1,07 & 1,39 & 1,71 & 0,61 & 0,93 & 1,25 & 1,58 \\
\hline & 25 & 1,08 & 1,40 & 1,72 & 2,04 & 0,79 & 1,11 & 1,43 & 1,75 & 0,62 & 0,94 & 1,26 & 1,58 \\
\hline & 30 & 1,18 & 1,50 & 1,82 & 2,14 & 0,83 & 1,15 & 1,47 & 1,79 & 0,62 & 0,95 & 1,27 & 1,59 \\
\hline & 35 & 1,28 & 1,60 & 1,92 & 2,24 & 0,87 & 1,19 & 1,51 & 1,84 & 0,63 & 0,95 & 1,27 & 1,59 \\
\hline & 40 & 1,38 & 1,70 & 2,02 & 2,34 & 0,91 & 1,23 & 1,55 & 1,88 & 0,64 & 0,96 & 1,28 & 1,60 \\
\hline & 45 & 1,46 & 1,80 & 2,12 & 2,44 & 0,95 & 1,27 & 1,60 & 1,92 & 0,64 & 0,96 & 1,28 & 1,60 \\
\hline & 50 & 1,57 & 1,90 & 2,22 & 2,54 & 0,99 & 1,31 & 1,64 & 1,96 & 0,65 & 0,97 & 1,29 & 1,61 \\
\hline \multirow{8}{*}{50} & 15 & 0,8 & 1,09 & 1,37 & 1,66 & 0,64 & 0,93 & 1,22 & 1,51 & 0,55 & 0,84 & 1,12 & 1,41 \\
\hline & 20 & 0,89 & 1,17 & 1,46 & 1,75 & 0,68 & 0,96 & 1,25 & 1,54 & 0,55 & 0,84 & 1,13 & 1,42 \\
\hline & 25 & 0,97 & 1,26 & 1,55 & 1,84 & 0,71 & 1,00 & 1,29 & 1,58 & 0,56 & 0,85 & 1,13 & 1,42 \\
\hline & 30 & 1,06 & 1,35 & 1,64 & 1,93 & 0,75 & 1,04 & 1,33 & 1,62 & 0,56 & 0,85 & 1,14 & 1,43 \\
\hline & 35 & 1,15 & 1,44 & 1,73 & 2,02 & 0,79 & 1,07 & 1,36 & 1,65 & 0,57 & 0,86 & 1,14 & 1,43 \\
\hline & 40 & 1,24 & 1,53 & 1,82 & 2,11 & 0,82 & 1,11 & 1,40 & 1,69 & 0,57 & 0,86 & 1,15 & 1,44 \\
\hline & 45 & 1,32 & 1,62 & 1,91 & 2,19 & 0,86 & 1,15 & 1,44 & 1,72 & 0,58 & 0,87 & 1,16 & 1,44 \\
\hline & 50 & 1,42 & 1,71 & 1,99 & 2,28 & 0,89 & 1,18 & 1,47 & 1,76 & 0,58 & 0,87 & 1,16 & 1,45 \\
\hline \multirow{8}{*}{55} & 15 & 0,72 & 0,99 & 1,25 & 1,51 & 0,58 & 0,84 & 1,11 & 1,37 & 0,50 & 0,76 & 1,02 & 1,28 \\
\hline & 20 & 0,81 & 1,07 & 1,33 & 1,59 & 0,61 & 0,88 & 1,14 & 1,40 & 0,50 & 0,76 & 1,03 & 1,29 \\
\hline & 25 & 0,89 & 1,15 & 1,41 & 1,67 & 0,65 & 0,91 & 1,17 & 1,44 & 0,51 & 0,77 & 1,03 & 1,29 \\
\hline & 30 & 0,97 & 1,23 & 1,49 & 1,75 & 0,68 & 0,94 & 1,21 & 1,47 & 0,51 & 0,77 & 1,04 & 1,30 \\
\hline & 35 & 1,05 & 1,31 & 1,57 & 1,83 & 0,71 & 0,98 & 1,24 & 1,50 & 0,52 & 0,78 & 1,04 & 1,30 \\
\hline & 40 & 1,13 & 1,39 & 1,65 & 1,91 & 0,75 & 1,01 & 1,27 & 1,53 & 0,52 & 0,78 & 1,05 & 1,31 \\
\hline & 45 & 1,21 & 1,47 & 1,73 & 1,99 & 0,78 & 1,04 & 1,31 & 1,57 & 0,53 & 0,79 & 1,05 & 1,31 \\
\hline & 50 & 1,29 & 1,55 & 1,81 & 2,08 & 0,81 & 1,08 & 1,34 & 1,60 & 0,53 & 0,79 & 1,05 & 1,32 \\
\hline \multirow{8}{*}{60} & 15 & 0,67 & 0,90 & 1,15 & 1,39 & 0,53 & 0,77 & 1,01 & 1,26 & 0,46 & 0,70 & 0,94 & 1,18 \\
\hline & 20 & 0,74 & 0,98 & 1,22 & 1,46 & 0,56 & 0,80 & 1,04 & 1,29 & 0,46 & 0,70 & 0,94 & 1,18 \\
\hline & 25 & 0,81 & 1,05 & 1,29 & 1,53 & 0,59 & 0,83 & 1,08 & 1,32 & 0,46 & 0,70 & 0,95 & 1,19 \\
\hline & 30 & 0,89 & 1,13 & 1,37 & 1,61 & 0,62 & 0,86 & 1,11 & 1,35 & 0,47 & 0,71 & 0,95 & 1,19 \\
\hline & 35 & 0,96 & 1,20 & 1,44 & 1,68 & 0,65 & 0,90 & 1,14 & 1,38 & 0,47 & 0,71 & 0,95 & 1,19 \\
\hline & 40 & 1,03 & 1,27 & 1,51 & 1,75 & 0,68 & 0,93 & 1,17 & 1,41 & 0,48 & 0,72 & 0,96 & 1,20 \\
\hline & 45 & 1,11 & 1,35 & 1,59 & 1,83 & 0,72 & 0,96 & 1,20 & 1,44 & 0,48 & 0,72 & 0,96 & 1,20 \\
\hline & 50 & 1,18 & 1,42 & 1,66 & 1,90 & 0,75 & 0,99 & 1,23 & 1,47 & 0,49 & 0,73 & 0,97 & 1,21 \\
\hline \multirow{8}{*}{65} & 15 & 0,61 & 0,83 & 1,06 & 1,28 & 0,49 & 0,71 & 0,94 & 1,16 & 0,42 & 0,64 & 0,86 & 1,09 \\
\hline & 20 & 0,68 & 0,90 & 1,13 & 1,35 & 0,52 & 0,74 & 0,96 & 1,19 & 0,42 & 0,65 & 0,87 & 1,09 \\
\hline & 25 & 0,75 & 0,97 & 1,19 & 1,42 & 0,55 & 0,77 & 0,99 & 1,21 & 0,43 & 0,65 & 0,87 & 1,09 \\
\hline & 30 & 0,82 & 1,04 & 1,26 & 1,48 & 0,58 & 0,80 & 1,02 & 1,24 & 0,43 & 0,65 & 0,88 & 1,10 \\
\hline & 35 & 0,89 & 1,11 & 1,33 & 1,55 & 0,60 & 0,83 & 1,05 & 1,27 & 0,44 & 0,66 & 0,88 & 1,10 \\
\hline & 40 & 0,95 & 1,18 & 1,40 & 1,62 & 0,63 & 0,85 & 1,08 & 1,30 & 0,44 & 0,66 & 0,88 & 1,11 \\
\hline & 45 & 1,02 & 1,24 & 1,47 & 1,69 & 0,66 & 0,88 & 1,10 & 1,33 & 0,44 & 0,67 & 0,89 & 1,11 \\
\hline & 50 & 1,09 & 1,31 & 1,53 & 1,76 & 0,69 & 0,91 & 1,13 & 1,35 & 0,45 & 0,67 & 0,89 & 1,11 \\
\hline \multirow{4}{*}{70} & 15 & 0,57 & 0,78 & 0,98 & 1,19 & 0,46 & 0,66 & 0,87 & 1,08 & 0,39 & 0,60 & 0,80 & 1,01 \\
\hline & 20 & 0,63 & 0,84 & 1,04 & 1,25 & 0,48 & 0,69 & 0,90 & 1,10 & 0,39 & 0,60 & 0,81 & 1,01 \\
\hline & 25 & 0,7 & 0,90 & 1,11 & 1,31 & 0,51 & 0,72 & 0,92 & 1,13 & 0,40 & 0,60 & 0,81 & 1,02 \\
\hline & 30 & 0,76 & 0,97 & 1,17 & 1,38 & 0,53 & 0,74 & 0,95 & 1,15 & 0,40 & 0,61 & 0,81 & 1,02 \\
\hline
\end{tabular}




\begin{tabular}{|c|c|c|c|c|c|c|c|c|c|c|c|c|c|}
\hline & 35 & 0,82 & 1,03 & 1,23 & 1,44 & 0,56 & 0,77 & 0,97 & 1,18 & 0,41 & 0,61 & 0,82 & 1,02 \\
\hline & 40 & 0,89 & 1,09 & 1,30 & 1,50 & 0,59 & 0,79 & 1,00 & 1,21 & 0,41 & 0,62 & 0,82 & 1,03 \\
\hline & 45 & 0,95 & 1,15 & 1,36 & 1,57 & 0,61 & 0,82 & 1,03 & 1,23 & 0,41 & 0,62 & 0,83 & 1,03 \\
\hline & 50 & 1,01 & 1,22 & 1,42 & 1,63 & 0,64 & 0,85 & 1,05 & 1,26 & 0,42 & 0,62 & 0,83 & 1,04 \\
\hline \multirow{8}{*}{75} & 15 & 0,53 & 0,72 & 0,92 & 1,11 & 0,43 & 0,62 & 0,81 & 1,00 & 0,36 & 0,56 & 0,75 & 0,94 \\
\hline & 20 & 0,59 & 0,78 & 0,98 & 1,17 & 0,45 & 0,64 & 0,84 & 1,03 & 0,37 & 0,56 & 0,75 & 0,95 \\
\hline & 25 & 0,65 & 0,84 & 1,03 & 1,23 & 0,48 & 0,67 & 0,86 & 1,05 & 0,37 & 0,56 & 0,76 & 0,95 \\
\hline & 30 & 0,71 & 0,90 & 1,09 & 1,29 & 0,50 & 0,69 & 0,88 & 1,08 & 0,37 & 0,57 & 0,76 & 0,95 \\
\hline & 35 & 0,77 & 0,96 & 1,15 & 1,34 & 0,52 & 0,72 & 0,91 & 1,10 & 0,38 & 0,57 & 0,76 & 0,96 \\
\hline & 40 & 0,83 & 1,02 & 1,21 & 1,40 & 0,55 & 0,74 & 0,93 & 1,13 & 0,38 & 0,57 & 0,77 & 0,96 \\
\hline & 45 & 0,89 & 1,08 & 1,27 & 1,46 & 0,57 & 0,76 & 0,96 & 1,15 & 0,39 & 0,58 & 0,77 & 0,96 \\
\hline & 50 & 0,94 & 1,14 & 1,33 & 1,52 & 0,60 & 0,79 & 0,98 & 1,17 & 0,39 & 0,58 & 0,77 & 0,97 \\
\hline \multirow{8}{*}{80} & 15 & 0,5 & 0,68 & 0,86 & 1,04 & 0,40 & 0,58 & 0,76 & 0,94 & 0,34 & 0,52 & 0,70 & 0,88 \\
\hline & 20 & 0,55 & 0,73 & 0,91 & 1,09 & 0,42 & 0,60 & 0,78 & 0,96 & 0,34 & 0,53 & 0,71 & 0,89 \\
\hline & 25 & 0,61 & 0,79 & 0,97 & 1,15 & 0,45 & 0,63 & 0,81 & 0,99 & 0,35 & 0,53 & 0,71 & 0,89 \\
\hline & 30 & 0,66 & 0,84 & 1,02 & 1,21 & 0,47 & 0,65 & 0,83 & 1,01 & 0,35 & 0,53 & 0,71 & 0,89 \\
\hline & 35 & 0,72 & 0,90 & 1,08 & 1,26 & 0,49 & 0,67 & 0,85 & 1,03 & 0,35 & 0,53 & 0,72 & 0,90 \\
\hline & 40 & 0,77 & 0,96 & 1,14 & 1,32 & 0,51 & 0,69 & 0,87 & 1,06 & 0,36 & 0,54 & 0,72 & 0,90 \\
\hline & 45 & 0,83 & 1,01 & 1,19 & 1,37 & 0,54 & 0,72 & 0,90 & 1,08 & 0,36 & 0,54 & 0,72 & 0,90 \\
\hline & 50 & 0,89 & 1,07 & 1,25 & 1,43 & 0,56 & 0,74 & 0,92 & 1,10 & 0,36 & 0,54 & 0,73 & 0,91 \\
\hline \multirow{8}{*}{85} & 15 & 0,47 & 0,64 & 0,81 & 0,98 & 0,38 & 0,55 & 0,72 & 0,89 & 0,32 & 0,49 & 0,66 & 0,83 \\
\hline & 20 & 0,52 & 0,69 & 0,86 & 1,03 & 0,40 & 0,57 & 0,74 & 0,91 & 0,32 & 0,49 & 0,66 & 0,83 \\
\hline & 25 & 0,57 & 0,74 & 0,91 & 1,08 & 0,42 & 0,59 & 0,76 & 0,93 & 0,33 & 0,50 & 0,67 & 0,84 \\
\hline & 30 & 0,62 & 0,79 & 0,96 & 1,13 & 0,44 & 0,61 & 0,78 & 0,95 & 0,33 & 0,50 & 0,67 & 0,84 \\
\hline & 35 & 0,68 & 0,85 & 1,02 & 1,19 & 0,46 & 0,63 & 0,80 & 0,97 & 0,33 & 0,50 & 0,67 & 0,84 \\
\hline & 40 & 0,73 & 0,90 & 1,07 & 1,24 & 0,48 & 0,65 & 0,82 & 0,99 & 0,34 & 0,51 & 0,68 & 0,85 \\
\hline & 45 & 0,78 & 0,95 & 1,12 & 1,29 & 0,50 & 0,67 & 0,84 & 1,01 & 0,34 & 0,51 & 0,68 & 0,85 \\
\hline & 50 & 0,83 & 1,00 & 1,17 & 1,34 & 0,53 & 0,70 & 0,87 & 1,04 & 0,34 & 0,51 & 0,68 & 0,85 \\
\hline \multirow{8}{*}{90} & 15 & 0,44 & 0,60 & 0,76 & 0,92 & 0,36 & 0,52 & 0,68 & 0,84 & 0,30 & 0,46 & 0,62 & 0,78 \\
\hline & 20 & 0,49 & 0,65 & 0,81 & 0,97 & 0,38 & 0,54 & 0,70 & 0,86 & 0,31 & 0,47 & 0,63 & 0,79 \\
\hline & 25 & 0,54 & 0,70 & 0,86 & 1,02 & 0,40 & 0,56 & 0,72 & 0,88 & 0,31 & 0,47 & 0,63 & 0,79 \\
\hline & 30 & 0,59 & 0,75 & 0,91 & 1,07 & 0,42 & 0,58 & 0,74 & 0,90 & 0,31 & 0,47 & 0,63 & 0,79 \\
\hline & 35 & 0,64 & 0,80 & 0,96 & 1,12 & 0,44 & 0,60 & 0,76 & 0,92 & 0,32 & 0,48 & 0,64 & 0,80 \\
\hline & 40 & 0,69 & 0,85 & 1,01 & 1,17 & 0,46 & 0,62 & 0,78 & 0,94 & 0,32 & 0,48 & 0,64 & 0,80 \\
\hline & 45 & 0,74 & 0,90 & 1,06 & 1,22 & 0,48 & 0,64 & 0,80 & 0,96 & 0,32 & 0,48 & 0,64 & 0,80 \\
\hline & 50 & 0,79 & 0,95 & 1,11 & 1,27 & 0,50 & 0,66 & 0,82 & 0,98 & 0,32 & 0,48 & 0,64 & 0,81 \\
\hline \multirow{7}{*}{95} & 15 & 0,42 & 0,57 & 0,72 & 0,88 & 0,34 & 0,49 & 0,64 & 0,79 & 0,29 & 0,44 & 0,59 & 0,74 \\
\hline & 20 & 0,47 & 0,62 & 0,77 & 0,92 & 0,36 & 0,51 & 0,66 & 0,81 & 0,29 & 0,44 & 0,59 & 0,75 \\
\hline & 25 & 0,51 & 0,66 & 0,82 & 0,97 & 0,38 & 0,53 & 0,68 & 0,83 & 0,29 & 0,45 & 0,60 & 0,75 \\
\hline & 30 & 0,56 & 0,71 & 0,86 & 1,02 & 0,39 & 0,55 & 0,70 & 0,85 & 0,30 & 0,45 & 0,60 & 0,75 \\
\hline & 35 & 0,61 & 0,76 & 0,91 & 1,06 & 0,41 & 0,57 & 0,72 & 0,87 & 0,30 & 0,45 & 0,60 & 0,75 \\
\hline & 40 & 0,65 & 0,80 & 0,96 & 1,11 & 0,43 & 0,58 & 0,74 & 0,89 & 0,30 & 0,45 & 0,61 & 0,76 \\
\hline & 45 & 0,7 & 0,85 & 1,00 & 1,15 & 0,45 & 0,60 & 0,76 & 0,91 & 0,30 & 0,46 & 0,61 & 0,76 \\
\hline \multirow{8}{*}{100} & 15 & 0,4 & 0,54 & 0,69 & 0,83 & 0,32 & 0,46 & 0,61 & 0,75 & 0,27 & 0,42 & 0,56 & 0,71 \\
\hline & 20 & 0,44 & 0,59 & 0,73 & 0,88 & 0,34 & 0,48 & 0,63 & 0,77 & 0,28 & 0,42 & 0,56 & 0,71 \\
\hline & 25 & 0,49 & 0,63 & 0,78 & 0,92 & 0,36 & 0,50 & 0,65 & 0,79 & 0,28 & 0,42 & 0,57 & 0,71 \\
\hline & 30 & 0,53 & 0,68 & 0,82 & 0,96 & 0,37 & 0,52 & 0,66 & 0,81 & 0,28 & 0,43 & 0,57 & 0,71 \\
\hline & 35 & 0,58 & 0,72 & 0,86 & 1,01 & 0,39 & 0,54 & 0,68 & 0,83 & 0,28 & 0,43 & 0,57 & 0,72 \\
\hline & 40 & 0,62 & 0,76 & 0,91 & 1,05 & 0,41 & 0,56 & 0,70 & 0,84 & 0,29 & 0,43 & 0,57 & 0,72 \\
\hline & 45 & 0,66 & 0,81 & 0,95 & 1,10 & 0,43 & 0,57 & 0,72 & 0,86 & 0,29 & 0,43 & 0,58 & 0,72 \\
\hline & 50 & 0,71 & 0,85 & 1,00 & 1,14 & 0,45 & 0,59 & 0,74 & 0,88 & 0,29 & 0,44 & 0,58 & 0,72 \\
\hline
\end{tabular}




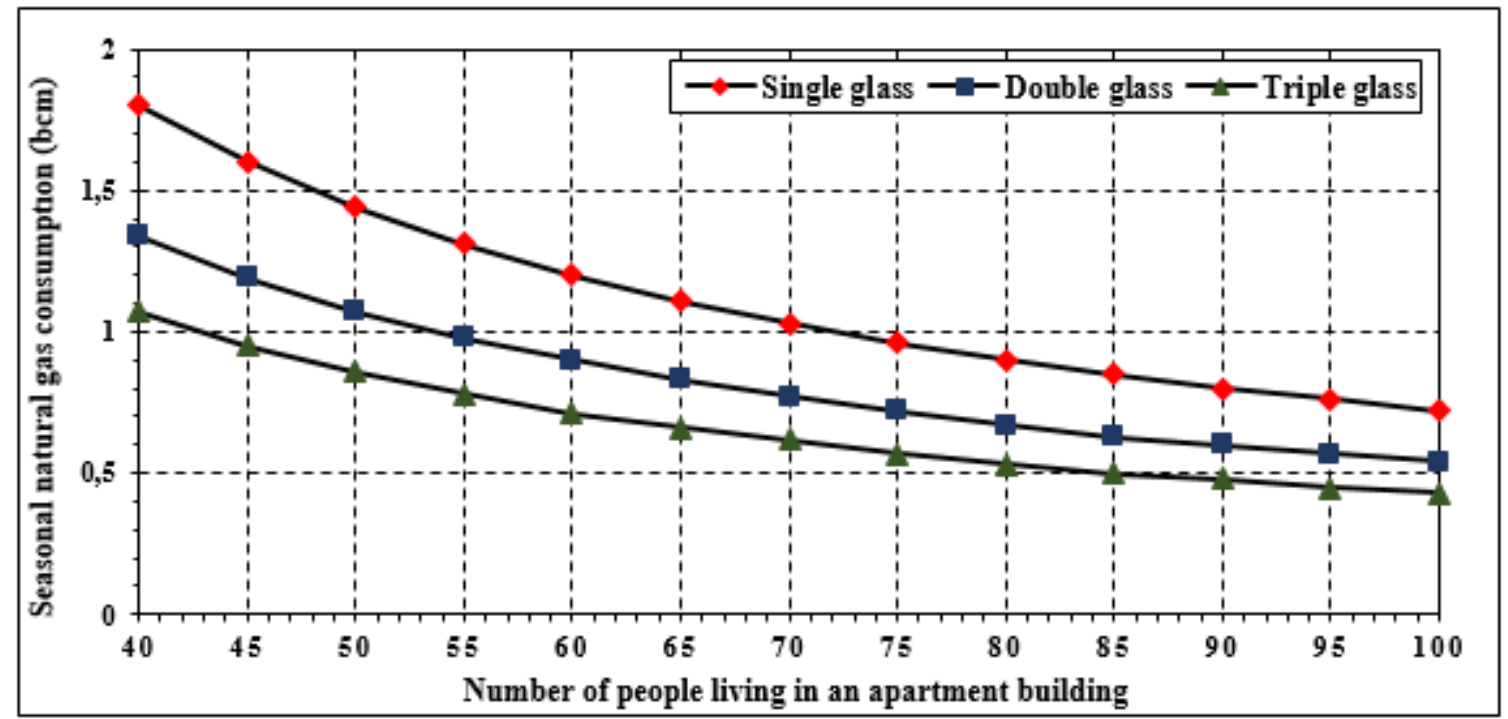

Fig. 5. Seasonal natural gas consumption in Kocaeli for $\mathrm{GAP}=35 \%$ and $I=1.0 \mathrm{ACH}$ versus number of people living in an apartment building.

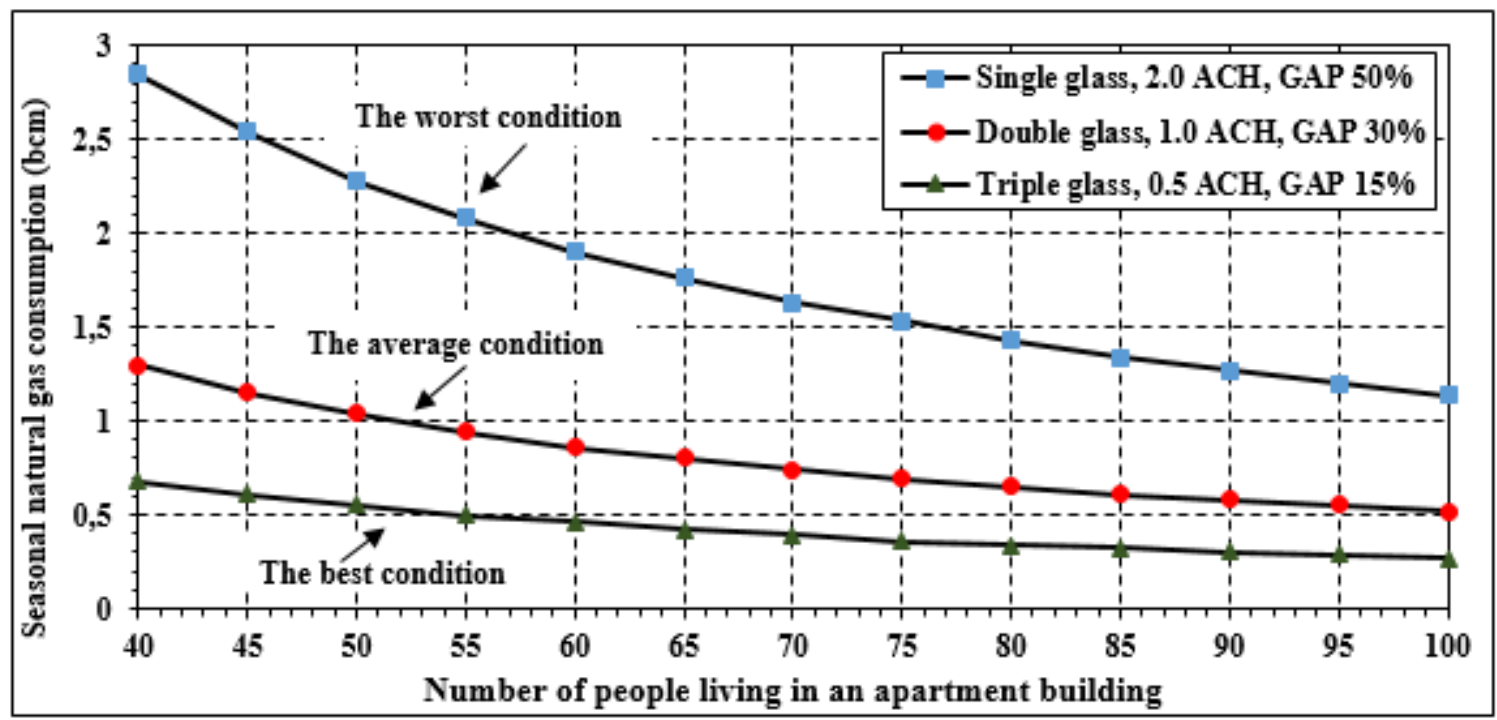

Fig. 6. Seasonal natural gas consumption in Kocaeli for the best, average and worst construction conditions vs number of people living in an apartment building.

\section{Conclusion and future work}

In this case study, the annual heating energy requirement and natural gas consumption were calculated for the building model with architectural design properties by using heating degree-day (HDD) method for the city of Kocaeli, based on temperature records at İzmit meteorology station located on the western coast of Turkey. It was observed that the 266th day (22 September) and 149th day (28 May) of the year appear as the beginning and end of the heating season if $T_{b}=15^{\circ} \mathrm{C}$ is considered. After determining amount of the annual natural gas consumption for Kocaeli, it was investigated that how the building exterior wall area, the air exchange rate, the type of glass used, the number of people living in the buildings affect the amount of fuel to be consumed.
It was identified that approximately $40 \%$ savings in annual fuel consumption are achieved in case of employing triple glass instead of single glass in residential buildings. It was also observed that air exchange rate influences the heating energy requirement significantly. Another parameter is the amount of glazed surface area in the buildings. It was seen by approximately twofold augmentation in fuel consumption in case this variable is increased from 20 to $50 \%$.

In addition to these, the architectural characteristics of the prototype building also significantly affect the energy demand. In the best conditions, the consumption for the example building model in Kocaeli is in the range of $0.27 \mathrm{bcm}$, while this value is nearly $2.85 \mathrm{bcm}$ in the worst case. 
The number of people living in an apartment building is moreover an substantial factor affecting the fuel consumption. Fuel consumption is positively affected by the increase in the number of people living in the building. If this value increases from 40 to 100 , natural gas consumption is reduced by almost 1.5 times.

If one of the other energy sources other than natural gas is employed, the annual energy load of a building can also be determined. By using the method given in this study, the heating energy requirement and fuel consumption in other cities of Turkey can be easily and safely calculated. The simple and useful method presented can be implemented in any other region of the desired world.

\section{References}

[1] K. Bilen, O. Ozyurt, K. Bakirci, S. Karsli, S. Erdogan, M. Yilmaz \& O. Comakli, "Energy production, consumption, and environmental pollution for sustainable development: A case study in Turkey ", Renewable and Sustainable Energy Reviews, vol. 12, pp. 1529-1561, 2008.

[2] T. Covert, M. Greenstone \& C. R. Knittel, "Will we ever stop using fossil fuels?", The Journal of Economic Perspectives, vol. 30, pp. 117-137, 2016.

[3] E. Akyuz, "Turkey's energy profile and the importance of renewable energy sources." Academic Sight, vol. 49, pp. 494504, 2015.

[4] M. Kadioglu \& Z. Sen, "Degree-day formulations and application in Turkey", Journal of Applied Meteorology, vol. 36, pp. 837-846, 1999.

[5] O. Kaynakli, "A review of the economical and optimum thermal insulation thickness for building applications", Renewable and Sustainable Energy Reviews, vol. 16, pp. 415425, 2012.

[6] A. K. Dagsoz \& K. G. Bayraktar, "The number of degreeday in Turkey and energy politics", Journal of Sanitary Engineering, pp. 32-40, 1999.

[7] A. Arisoy, İklim Verileri, III. Uluslar arası Yapıda Tesisat Bilimi ve Teknolojisi Sempozyumu, 1998.

[8] A. Durmayaz, M. Kadioglu \& Z. Sen, "An application of the degree-hours method to estimate the residential heating energy requirement and fuel consumption in Istanbul", Energy, vol. 25, pp. 1245-1256, 2000.

[9] A. K. Dagsoz, "Degree Day Values in Turkey, National energy saving policy, Heat insulation in buildings", Istanbul: Izocam, 1995.
[10] H. Sarak \& A. Satman, "The degree-day method to estimate the residential heating natural gas consumption in Turkey: a case study", Energy, vol. 28, pp. 929-939, 2003.

[11] S. Akbayir, "Derece gün metodu ve Eskişehir için derece gün değerlerinin tespiti, Yüksek lisans tezi, O.G.Ü, 2006.

[12] O. Kaynakli, "A study on residential heating energy requirement and optimum insulation thickness", Renewable Energy, vol. 33, pp. 1164-1172, 2008.

[13] A. Durmayaz \& M. Kadioglu, "Heating energy requirements and fuel consumptions in the biggest city centers of Turkey", Energy Conversion and Management, vol. 44, pp. 1177-1192, 2003.

[14] A. F. Emery \& C. J. Kippenhan, "A long term study of residential home heating consumption and the effect of occupant behavior on homes in the Pacific Northwest constructed according to improved thermal standards", Energy, vol. 31, pp. 677-693, 2006.

[15] J. F. Kreider \& A. Rabl, "Heating and cooling of buildings: design for efficiency McGraw-Hill", New York, 1994.

[16] S. Usta, "TS 825 "Binalarda Is1 Yalıtım Kuralları" Standardına Göre İkinci Bölgede Bulunan Bir Binanın Yalıtımsız ve Yalıtımlı Durumlarının Enerji Verimliliği Bakımından Karşılaştırılması." Electronic Journal of ConstructionTechnologies, vol. 5, pp. 1-24, 2009.

[17] ASHRAE Handbook Fundamentals, "American society of heating, refrigerating and air-conditioning engineers", Inc. , 2009.

[18] A. Satman \& N. Yalcinkaya, "Heating and cooling degree-hours for Turkey", Energy, vol. 24, pp. 833-840, 1999.

[19] J. A. Duffie \& W. A. Beckman, "Solar engineering of thermal processes", John Wiley \& Sons, 2013. 